\title{
RADIOCARBON DATING OF NEOLITHIC POTTERY
}

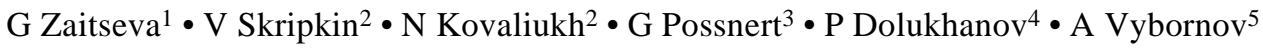

ABSTRACT. The direct measurement of organic matter included in archaeological pottery may yield a reliable assessment of age. The main problem consists in the identification of possible origins and assessment of distortion for the age of organic inclusions. Our experiments show that shells included in pottery fabrics are strongly influenced by the reservoir effect, which may reach $500 \mathrm{yr}$ or more. Other organic inclusions, such as lake ooze, do not visibly distort the age. The obtained series of radiocarbon dates have been used for the assessing the age of the early stages of pottery manufacture in southern Russia.

\section{INTRODUCTION}

In principle, pottery is a promising material for dating because it is directly related to the archaeological context. The age of pottery assemblages until quite recently was usually estimated based on radiocarbon dates of samples of organic matter from the objects (hearths, seeds, wooden structures), which were deemed as synchronous with the pottery. However, this synchronicity can never be absolute. Hence, since the 1950s, attempts have been made to directly measure organic carbon derived from the pottery matrix. Kohl and Quitta (1964) were among the first who obtained dates for the early Neolithic LBK by direct dating of pottery carbon.

With the use of conventional ${ }^{14} \mathrm{C}$ dating, the necessary amount of carbon ( $1 \mathrm{~g}$ of elementary carbon) was too large and necessitated the grinding of unacceptably large amounts of pottery. The situation has drastically changed with the advent of accelerator mass spectrometry (AMS) technology, which enabled the dating of much smaller samples. Yet many problems related to ${ }^{14} \mathrm{C}$ dating of pottery remain unresolved.

There are sites where pottery constitutes the main material for dating in the absence of other datable organic materials, excluding animal bones. Sites of this type, indicative of early stages of potterymaking, were found in the southern regions of Russia, and the exact determination of their age is of paramount importance. The subject of this paper is the techniques used for direct dating of the organic matter included in the pottery fabrics, with a discussion of the obtained results.

The principle problem consists in the identification of the sources of organic matter embedded in the pottery fabrics. Several possible sources are acknowledged (Bonsall et al. 2002):

1. Carbon, penetrated jointly with the clay, and which had arisen in a distant geological past. Hence, its age may be much older than that of the pottery. In the clay usually used for potterymaking, this amount varies in the range of $0.05-0.2 \%$, with limited deviations within a single outcrop;

2. Carbon derived from the temper (grass, straw, chaff, dung, and ground shells). The contemporaneity of these inclusions with the pottery-making and possible distortion of ${ }^{14} \mathrm{C}$ age are discussed below;

3. Carbon absorbed from fuel while firing in the kiln;

\footnotetext{
${ }^{1}$ Institute for History of Material Culture, St. Petersburg, Russia. Corresponding author. Email: ganna@mail.wplus.net.

${ }^{2}$ Institute of the Geochemistry of Environment, National Academy of Sciences of Ukraine, Kiev, Ukraine.

${ }^{3}$ University of Uppsala, Uppsala, Sweden.

${ }^{4}$ Newcastle University, Newcastle upon Tyne, United Kingdom.

${ }^{5}$ State Pedagogical University, Samara, Russia.
}

(C) 2009 by the Arizona Board of Regents on behalf of the University of Arizona

Proceedings of the 5th International ${ }^{14} \mathrm{C}$ and Archaeology Symposium, edited by Irka Hajdas et al.

RADIOCARBON, Vol 51, Nr 2, 2009, p 795-801 
4. Carbon from food residues, the dates of which are usually deemed the most reliable. These residues are comparatively rare, however, and in some cases pose problems related to the reservoir effect;

5. Carbon resulting from contamination from the surrounding soil, mostly humic acids, may be easily removed by chemical treatment.

\section{METHODS}

Taking into account the above-mentioned limitations, the technology developed at the Kiev ${ }^{14} \mathrm{C}$ Laboratory, Institute of Environmental Geochemistry, enables one to obtain 95\% benzene output with a near total absence of memory effect (Buzinny and Skripkin 1995). A Quantulus alpha-beta spectrometer was used, specially designed for low-background samples, using the vials to measure a small amount of the benzene.

Pottery samples of 200-400 g with a carbon content of 1-3\% were taken from the vessel walls, and, rarely, from the bottom. The ground samples (10-22 $\mathrm{mm}$ in diameter) were treated with $0.5 \mathrm{~N}$ hydrofluoric acid in a Teflon ${ }^{\circledR}$ container for $2-5 \mathrm{hr}$ under indoor temperature. At the initial and final stages, the samples were subject to $10 \mathrm{~min}$ of ultrasonic exposure.

The samples were then finely ground, dried under $150-180^{\circ} \mathrm{C}$, and mixed with a calculated amount of manganese dioxide; the gaseous products were absorbed by lithium. The lithium carbide is synthesized with the use of "vacuum pyrolysis" (Skripkin and Kovalyukh 1998). The benzene was synthesized in a stainless steel reactor (Figure 1) under 0.1-2 atm of pressure. With the temperature rising above $550{ }^{\circ} \mathrm{C}$, the manganese dioxide disintegrates with the uniform release of the active oxygen in a wide temperature range of $550-940{ }^{\circ} \mathrm{C}$. The fine-dyspersated carbon was oxidized, forming carbon oxide and dioxide, which are absorbed by the melted metallic lithium. The lithium carbide is subjected to hydrolysis, and the released acetylene is turned into benzene with a vanadium catalyst.

Figure 1 The principle scheme of the $\mathbf{t}=\mathbf{7 5 0 - 8 5 0 \quad c}=$ reactor to obtain benzene for the liquid scintillation technique.

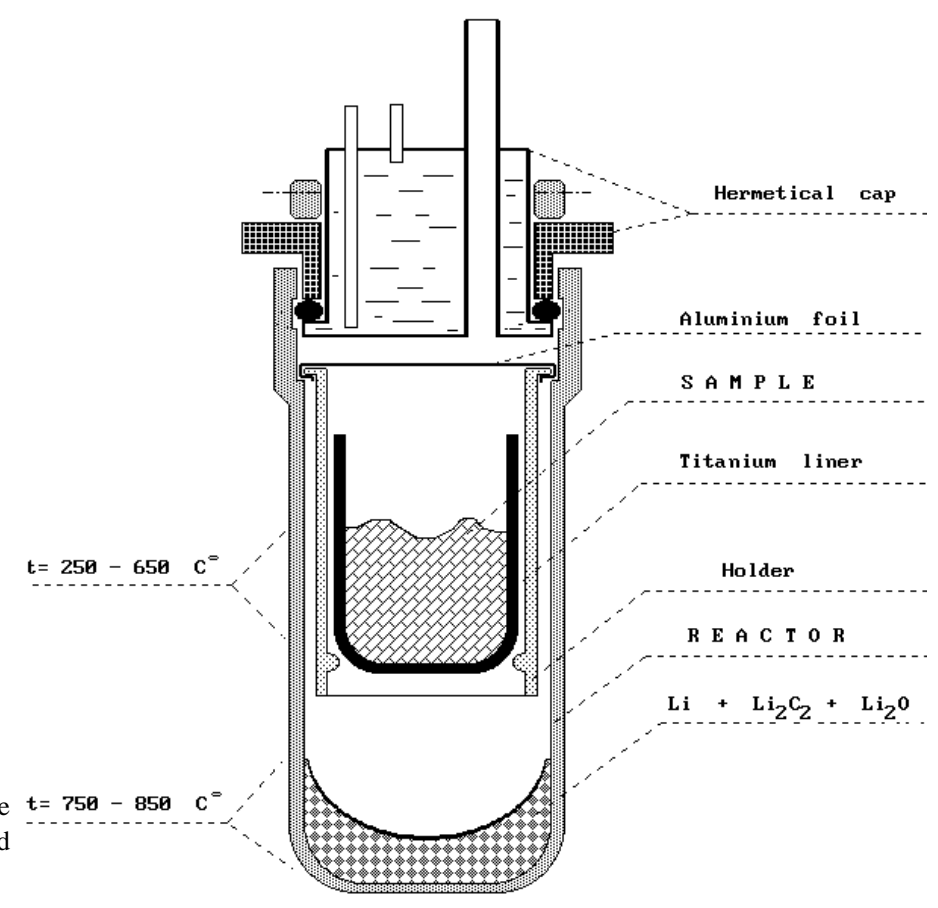




\section{YELSHANIAN CULTURE}

The Yelshanian-type pottery as the earliest technology of this kind on East European Plain has been first recognized by I B Vasil'ev in the Samara-Volga area in the 1970s (Yudin 2005). By now, the typical "Yelshanian assemblage" has been identified at several sites: Staraya Yelshanka I, II, Maksimovo, Chekalino, Lower Orlyanka, Ivanovka, Lugovoye III, Lebyazh'ye I, Bol'she-Rakopvskaya, Il'ynskaya, Krasnyi Gorodok, Zakhar-Kolma, Vilovatovskaya, and a few more (Mamonov 1995). Amongst all these sites, the "pure Yelshanian element" has been recognized only in 2 cases, the lower strata of Chekalino IV and Lower Orlyanka II. (Figure 2, \#9-14).

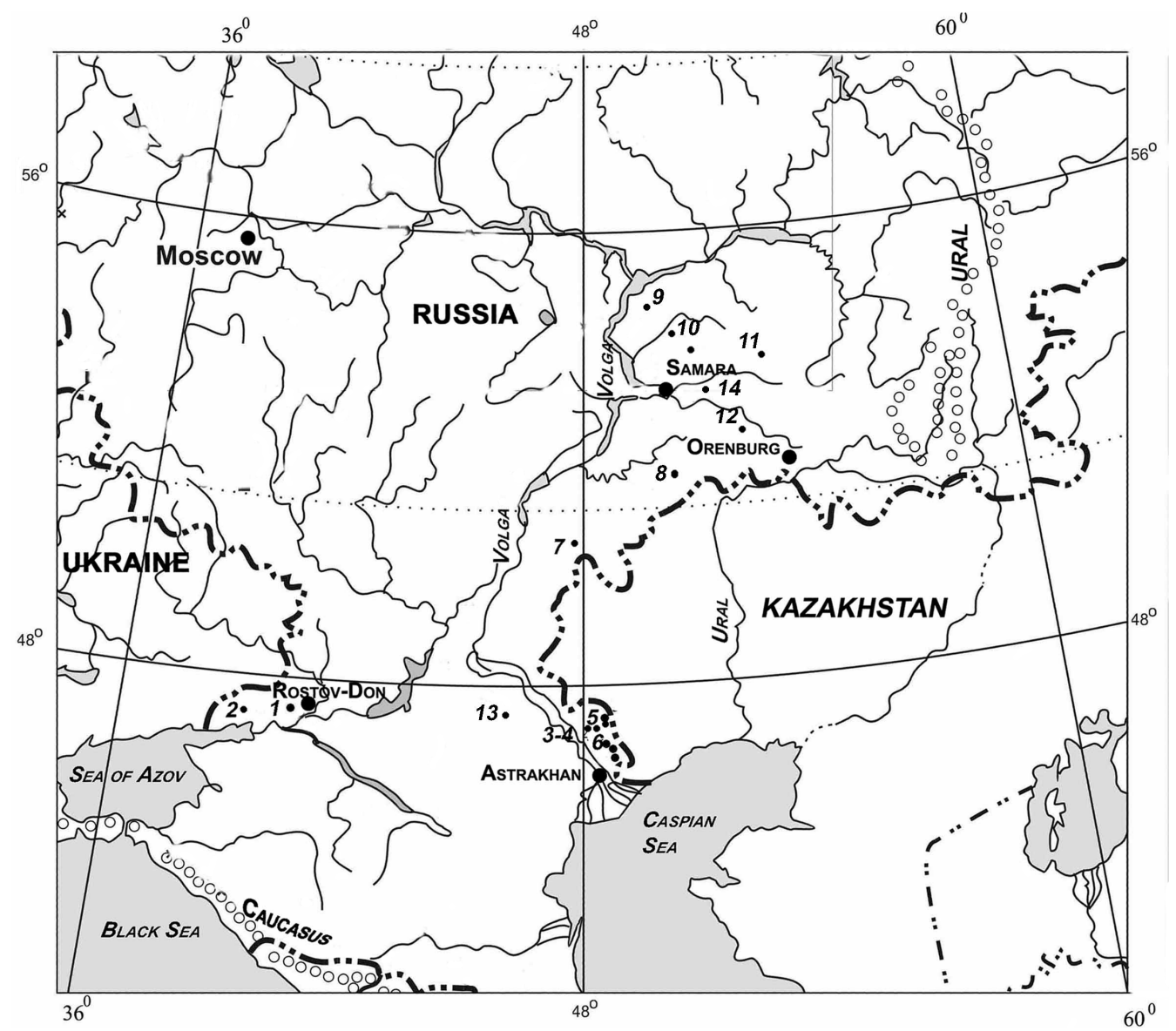

Figure 2 Map of the Neolithic sites in southern Russia and the Lower Volga River basin regions investigated: 1Rakushechny Yar; 2-Matveyev kurgan; 3-Kairshak I-III; 4-Kugat IV; 5-Tektensor I, III; 6-Burovaya; 7-Varfolomeyevka; 8-Lebyazhinka; 9-Yelshanka; 10-Chekalino IV; 11-Maksimovka; 12-Ivanovskoe; 13-Dzangar; 14-Il'inka.

As the microscopic studies have shown, this pottery was manufactured from the local sandy clay, which included a natural admixture of organic matter and small fragments of mollusk shells. In rare cases, one notes the tempering by chamotte or old, crumbled pottery sherds. The vessels were fired in open hearths at temperatures not exceeding $450{ }^{\circ} \mathrm{C}$. The majority of pottery vessels were not ornamented. Rarely, incised lines, pit impressions, or short notches, forming zigzag patterns, are seen. Several vessels were decorated by a belt beneath the rim consisting of pits and "pearl" impressions. 
Presently, $25{ }^{14} \mathrm{C}$ dates are available for Yelshanian sites (Table 1). There are notable differences in the age obtained for the same site from different materials. Thus, the ${ }^{14} \mathrm{C}$ dates obtained for the freshwater shells from the cultural layers of Lebyazhinka IV and Chekalino-IV sites (about 8990$7940 \mathrm{BP})$ are older than those for the carbon in the pottery of the same sites (6100-5940 BP).

Table $1{ }^{14} \mathrm{C}$ dates of the Neolithic sites of the Volga River basin region.

\begin{tabular}{lllll}
\hline Site & Index & Material & Age BP & Age, cal BC $(2 \sigma)$ \\
\hline Lebyazhinka IV & GIN-7088 & Shells & $8470 \pm 140$ & $7950-7050$ \\
Lebyazhinka IV & Ki-14468 & Pottery carbon & $5970 \pm 80$ & $5100-4600$ \\
Yelshanka & Ki-14569 & Pottery carbon & $6760 \pm 80$ & $5800-5510$ \\
Yelshanka & Ki-14570 & Pottery carbon & $6480 \pm 80$ & $5610-5300$ \\
Chekalino IV & Le-4782 & Shells & $8000 \pm 120$ & $7350-6550$ \\
Chekalino IV & Le-4784 & Shells & $7940 \pm 140$ & $7300-6450$ \\
Chekalino IV & GIN-7084 & Shells & $7950 \pm 130$ & $7300-6450$ \\
Chekalino IV & Le-4781 & Shells & $8990 \pm 100$ & $8450-7750$ \\
Chekalino IV & GIN-7085 & Shells & $8680 \pm 120$ & $8250-7500$ \\
Chekalino IV & Ki-14686 & Pottery carbon & $5910 \pm 90$ & $5000-4540$ \\
Chekalino IV & Ki-14687 & Humic acids & $6030 \pm 100$ & $5300-4650$ \\
Chekalino IV & Ki-14688? & Pottery carbon & $5870 \pm 80$ & $4940-4530$ \\
Chekalino IV & Ki-14689 & Shells & $6100 \pm 140$ & $5400-4650$ \\
Chekalino IV & Le-4783 & Shells & $7940 \pm 140$ & $7300-6450$ \\
Maksimovka 2 & Ki-14411 & Pottery carbon & $6430 \pm 80$ & $5560-5250$ \\
Maksimovka 2 & Ki-14412 & Pottery carbon & $6470 \pm 80$ & $5640-5300$ \\
Ivanovka & Le-2343 & Pottery carbon & $8020 \pm 90$ & $7300-6650$ \\
Ivanovka & Ki-14658 & Pottery carbon & $7930 \pm 80$ & $7060-6630$ \\
Ivanovka & Ki-14567 & Pottery carbon & $7150 \pm 90$ & $6220-5830$ \\
Ivanovka & Ki-14568 & Pottery carbon & $7680 \pm 90$ & $6700-6260$ \\
Ivanovka & Ki-14568 & Pottery carbon & $7930 \pm 90$ & $7100-6550$ \\
Ivanovka & Ki-14567 & Pottery carbon & $7680 \pm 90$ & $6700-6260$ \\
Ivanovka & Ki-14631 & Pottery carbon & $7780 \pm 90$ & $7050-6400$ \\
Staroyelshanka II & Ki-14413 & Pottery carbon & $6820 \pm 80$ & $5880-5550$ \\
Il'inka & Le-5839 & Shells & $8510 \pm 60$ & $7650-7370$ \\
\hline & & & & \\
\hline & & & &
\end{tabular}

\section{NORTHERN CASPIAN AREA}

The sites attributed to the Mesolithic and Neolithic sites in the Caspian Lowland and along the Lower Volga discovered since the 1980s, include Kairshak (Figure 2, \#3), Tenkeskor (Figure 2, \#5), Varfolomeyevka (Figure 2, \#7), and many others. Based on typological grounds (Vasil'ev and Vybornov 1988; Vybornov 1990, 2008), 2 cultural groups were distinguished for the North Caspian early Neolithic: Kairshak-Tenteksorian and Jangar-Varfolomeyvian, which form together the Lower Volga cultural entity. The pottery consists of straight-walled vessels with round bases manufactured from clay with crushed shells and plant remains.

More than $50{ }^{14} \mathrm{C}$ dates for the 10 sites are available for the North Caspian area (Table 2). The majority of these dates has been obtained by direct dating of organic matter in pottery, using the methodology described above. In some cases, discrepancies between the measurements of various materials from the same sites are apparent. Thus, the dates obtained from the charcoal of the cultural layer of the Kairshak-III site are younger than those from the pottery carbon. This suggests that some of the dated materials were affected by the processes, which notably distorted their age. To test this hypothesis and to identify the possible sources of age distortions, we conducted multiple analyses of pot fragments from the site of the Tenteksor I. 
Table 2 The ${ }^{14} \mathrm{C}$ dates of the Neolithic sites of the Caspian see region.

\begin{tabular}{|c|c|c|c|c|}
\hline Site & Index & Material & Age (BP) & Age, cal BC $(2 \sigma)$ \\
\hline Kairshak III & GIN-5905 & Charcoal & $6950 \pm 190$ & $6250-5450$ \\
\hline Kairshak III & GIN-5927 & Charcoal & $6720 \pm 80$ & $5740-5480$ \\
\hline Kairshak III & $\mathrm{Ki}-14133$ & Pottery carbon & $7950 \pm 90$ & $7080-6590$ \\
\hline Kairshak III & Ki-14097 & Pottery carbon & $7890 \pm 90$ & $7100-6500$ \\
\hline Kairshak III & Ki-14471 & Pottery carbon & $7780 \pm 90$ & $7050-6400$ \\
\hline Kairshak III & $\mathrm{Ki}-14095$ & Pottery carbon & $7740 \pm 70$ & $6700-6430$ \\
\hline Kairshak III & $\mathrm{Ki}-14096$ & Pottery carbon & $7680 \pm 90$ & $6700-6260$ \\
\hline Kairshak III & $\mathrm{Ki}-14632$ & Pottery carbon & $7530 \pm 90$ & $6530-6210$ \\
\hline Kugat IV & $\mathrm{Ki}-14501$ & Pottery carbon & $7680 \pm 80$ & $6690-6380$ \\
\hline Kugat IV & $\mathrm{Ki}-14500$ & Pottery carbon & $7560 \pm 90$ & $6600-6220$ \\
\hline Kairshak I & Ki-14094 & Pottery carbon & $7230 \pm 90$ & $6390-6010$ \\
\hline Kairshak I & $\mathrm{Ki}-14132$ & Pottery carbon & $7180 \pm 90$ & $6230-5840$ \\
\hline Kairshak III, upper layer & $\mathrm{Ki}-14633$ & Animal bone & $7190 \pm 80$ & $6230-5890$ \\
\hline Kairshak III, upper layer & Ki14634 & Animal bone & $7010 \pm 80$ & $6020-5720$ \\
\hline Kairshak IV & Ki-14440a & Pottery carbon & $7105 \pm 90$ & $6170-5770$ \\
\hline Kairshak IV & Ki-14440b & Pottery carbon & $6960 \pm 80$ & $6000-5710$ \\
\hline Burovaya 42 & Ki-14444 & Pottery carbon & $6920 \pm 90$ & $5990-5630$ \\
\hline Tenteksor III & $\mathrm{Ki}-14445$ & Pottery carbon & $7005 \pm 90$ & $6030-5710$ \\
\hline Kachkarstau & Ki-14461 & Pottery carbon & $6730 \pm 80$ & $5750-5480$ \\
\hline Tenteksor I & GIN-6177 & Humic acids & $5500 \pm 150$ & $4700-3950$ \\
\hline Tenteksor I & $\mathrm{Ki}-14101$ & Pottery carbon & $6640 \pm 80$ & $5720-5470$ \\
\hline Tenteksor I & $\mathrm{Ki}-14137$ & Pottery carbon & $6630 \pm 80$ & $5720-5460$ \\
\hline Kyzylkhak & $\mathrm{Ki}-14443$ & Pottery carbon & $6400 \pm 90$ & $5600-5050$ \\
\hline Kyzylkhak & $\mathrm{Ki}-1443$ & Pottery carbon & $5905 \pm 100$ & $5050-4500$ \\
\hline Jangar, layer 1 & Le-2901 & Charcoal & $5890 \pm 70$ & $4940-4550$ \\
\hline Jangar, layer 1 & $\mathrm{Ki}-14643$ & Pottery carbon & $5480 \pm 80$ & $4490-4040$ \\
\hline Jangar, layer 2 & Le-2564 & Charcoal & $6100 \pm 70$ & $5260-4800$ \\
\hline Jangar, layer 2 & $\mathrm{Ki}-14641$ & Pottery carbon & $6780 \pm 90$ & $5840-5510$ \\
\hline Jangar, layer 2 & $\mathrm{Ki}-14642$ & Pottery carbon & $6680 \pm 90$ & $5740-5470$ \\
\hline Jangar, layer 3 & Ki-14639 & Pottery carbon & $7080 \pm 90$ & $6160-5740$ \\
\hline Jangar, layer 3 & $\mathrm{Ki}-14640$ & Pottery carbon & $6990 \pm 90$ & $6030-5710$ \\
\hline Varfolomeyevka 2A & $\mathrm{Ki}-3589$ & Animal bone & $5430 \pm 60$ & $4350-4040$ \\
\hline Varfolomeyevka 2A & $\mathrm{Ki}-3595$ & Animal bone & $5390 \pm 60$ & $4350-4040$ \\
\hline Varfolomeyevka 2A & $\mathrm{Ki}-3590$ & Animal bone & $5270 \pm 50$ & $4230-3970$ \\
\hline Varfolomeyevka 2A & $\mathrm{Ki}-3596$ & Animal bone & $5220 \pm 50$ & $4230-3940$ \\
\hline Varfolomeyevka 2A & $\mathrm{Ki}-14372$ & Pottery carbon & $7100 \pm 50$ & $6070-5840$ \\
\hline Varfolomeyevka 2A & $\mathrm{Ki}-14375$ & Pottery carbon & $6970 \pm 80$ & $6010-5710$ \\
\hline Varfolomeyevka 2A & $\mathrm{Ki}-14371$ & Pottery carbon & $6890 \pm 80$ & $5980-5610$ \\
\hline Varfolomeyevka 2A & $\mathrm{Ki}-14373$ & Pottery carbon & $6860 \pm 90$ & $5980-5630$ \\
\hline Varfolomeyevka 2A & $\mathrm{Ki}-14613$ & Pottery carbon & $6540 \pm 80$ & $5622-5340$ \\
\hline Varfolomeyevka 2A & $\mathrm{Ki}-14637$ & Pottery carbon & $6040 \pm 80$ & $5210-4720$ \\
\hline Varfolomeyevka 2A & $\mathrm{Ki}-14614$ & Pottery carbon & $5870 \pm 80$ & $4940-4530$ \\
\hline Varfolomeyevka 2A & $\mathrm{Ki}-14612$ & Pottery carbon & $5810 \pm 80$ & 4844-4461 \\
\hline Varfolomeyevka 2B & Lu-2642 & Pottery carbon & $6400 \pm 230$ & $5750-4800$ \\
\hline Varfolomeyevka 2B & Lu-2620 & Pottery carbon & $6040 \pm 160$ & $5350-4550$ \\
\hline Varfolomeyevka 2B & $\mathrm{Ki}-14374$ & Pottery carbon & $7280 \pm 100$ & $6390-5920$ \\
\hline Varfolomeyevka 2B & $\mathrm{Ki}-14368$ & Pottery carbon & $7230 \pm 90$ & $6250-5890$ \\
\hline Varfolomeyevka 2B & Ki-14370 & Pottery carbon & $7070 \pm 90$ & $6160-5730$ \\
\hline Varfolomeyevka 2B & $\mathrm{Ki}-14639$ & Pottery carbon & $6980 \pm 90$ & $6020-5710$ \\
\hline
\end{tabular}


Table 2 The ${ }^{14} \mathrm{C}$ dates of the Neolithic sites of the Caspian see region. (Continued)

\begin{tabular}{lllll}
\hline Site & Index & Material & Age $(\mathrm{BP})$ & Age, cal BC $(2 \sigma)$ \\
\hline Varfolomeyevka, layer 3 & GIN-6546 & Pottery carbon & $6980 \pm 200$ & $6250-5450$ \\
Varfolomeyevka, layer 3 & Ki-14108 & Pottery carbon & $7760 \pm 100$ & $7050-6400$ \\
Varfolomeyevka, layer 3 & Ki-14142 & Pottery carbon & $7620 \pm 100$ & $6650-6230$ \\
Varfolomeyevka, layer 3 & Ki-14109 & Pottery carbon & $7250 \pm 80$ & $6250-5920$ \\
Varfolomeyevka, layer 3 & Ki-14143 & Pottery carbon & $7170 \pm 90$ & $6230-5840$ \\
Varfolomeyevka, layer 3 & Ki-14110 & Pottery carbon & $7080 \pm 80$ & $6160-5770$ \\
Varfolomeyevka, layer 3 & Ki-14144 & Pottery carbon & $7120 \pm 90$ & $6207-5790$ \\
\hline
\end{tabular}

\section{TENTEKSOR CASE STUDY}

The Tenteksor I site occupies an area of about $300 \mathrm{~m}^{2}$ and includes remains of a surface dwelling. The fragments of more than 170 vessels found at the site belonged to both profiled and straightwalled flat-based pots with either rounded or flat rims. They were made of clay tempered with crushed shells and vegetable matter. The ornament restricted to the upper portion of the vessels consisted of receding oval or square impressions, forming horizontal rows, rhombi, meanders, zigzags, triangles, and rectangles.

To test the reliability of direct pottery dating, microscopically visible plant remains and Valvata shell particles were extracted from the pottery mass and separately dated by AMS facilities at the Laboratory of Uppsala University (Sweden).

The measured age of the shells was $7235 \pm 45 \mathrm{BP}$ with $\delta^{13} \mathrm{C}=-13.3 \%$ o (Ua-35226). That of the charcoal after the acid treatment was found to be $6695 \pm 40 \mathrm{BP}$ with $\delta^{13} \mathrm{C}=-27.7 \%$. The pottery fragments were consequently separated into inner ("the "terra-cotta" red-colored portion) and outer parts (the darker one). The shell particles were separated and treated by the $\mathrm{HCl}$ solution. After the treatment, the shells were dated by AMS. The remaining darker part was treated by hydrofluoric acid, to remove the contaminants. Following treatment, the darker part was also dated by AMS.

The ${ }^{14} \mathrm{C}$ age obtained for the darker part was $6695 \pm 40 \mathrm{BP}$ with $\delta^{13} \mathrm{C}=-27.7 \%$ (Ua-35227). This age is practically identical with that obtained at the Kiev Laboratory, $6630 \pm 80 \mathrm{BP}$ (Ki-14137), using liquid scintillation and the chemical pretreatment described above (Table 3).

Table $3{ }^{14} \mathrm{C}$ ages obtained for the pottery sample from Tenteksor I site at the Kiev Laboratory (liquid scintillation technique) and University of Uppsala (AMS).

\begin{tabular}{lllll}
\hline Lab code & Material & ${ }^{14} \mathrm{C}$ age $(\mathrm{BP})$ & $\begin{array}{l}\delta^{13} \mathrm{C} \\
(\%)\end{array}$ & $\begin{array}{l}\text { Calibrated age } \\
( \pm 2 \sigma)\end{array}$ \\
\hline Ua-35226 & Shells from pottery & $7235 \pm 45$ & -13.3 & $6220-6000$ \\
Ua-35227 & $\begin{array}{l}\text { Carbon from the pottery, } \\
\text { darker part }\end{array}$ & $6695 \pm 40$ & -27.7 & $\begin{array}{l}5720-5680(78.9 \%) ; \\
5670-5520(89.5 \%)\end{array}$ \\
Ki-14137 & Pottery carbon, entire sample & $6630 \pm 80$ & - & $5730-5460$ \\
\hline
\end{tabular}

The differences in the ${ }^{14} \mathrm{C}$ dates obtained for the shells and the "darker" constituent of the pottery can be explained by the reservoir effect, which considerably distorted the age of the shells. The difference in the ${ }^{14} \mathrm{C}$ age of the shell and pottery carbon is about $550 \mathrm{yr}$. Significantly, the reservoir effect for lake fish is estimated in the range of 500-1500 yr, whereas this effect was not observed for animal bones (Van Strydonck et al. 2004). 
Over the past few decades, new and impressive data sets of early pottery-bearing sites in the southern and southeastern areas of the East European Plain became available. They show an unexpectedly old age, often exceeding that of early farming sites in southeastern Europe. A large amount of these dates were obtained by means of direct dating of organic matter included in the pottery fabric.

The authenticity of these dates raises serious questions. The main problem consists in identifying the sources of origins of organic inclusions in the pottery and the possible distortion of their ${ }^{14} \mathrm{C}$ age. The current experiments show that pottery may be considered as a valid material for ${ }^{14} \mathrm{C}$ dating, provided several basic requirements are met.

As demonstrated above, the shells included in the pottery fabric are strongly influenced by the reservoir effect, which may exceed 500 yr. Therefore, first of all, pottery shells should be microscopically scanned in order to identify the temper and remove the shells. Secondly, the samples should be treated with diluted $\mathrm{HCl}$ and $\mathrm{HF}$ acids, destroying the shells as well as the silica aggregates. Other organic inclusions, such as lake ooze, do not visibly distort the age.

\section{CONCLUSIONS}

The obtained data prove the reliability of ${ }^{14} \mathrm{C}$ dating of pottery carbon, after the necessary chemical pretreatment and the removal the carbonates and shells in particular. The methodology developed at the Kiev Radiocarbon Laboratory makes feasible the dating of pottery carbon with the use of conventional dating. The newly obtained dates for pottery carbon lay a solid foundation for the chronology of early pottery culture in the southern East European Plain.

\section{ACKNOWLEDGMENT}

This research is supported by F6 European Project FEPRE. No. 028192.

\section{REFERENCES}

Bonsall C, Cook G, Manson JL, Saderson D. 2002. Direct dating of Neolithic pottery: progress and prospects. Documenta Praehistorica XXIX:47-59.

Buzinny M, Skripkin V. 1995. Newly designed 0.8-mL Tephlon ${ }^{\circledR}$ vial for microvolume radiocarbon dating. Radiocarbon 37(2):743-7.

Kohl G, Quitta H. 1964. Berlin radiocarbon measurements I. Radiocarbon 6:308-17.

Mamonov AE. 1995. Yelshanskii kompleks stojanki Chekalino IV. In: Vasil'ev IB, editor. Drevnie kul'tury lesostepnogo Povolzh'ya. Samara: Samara State Pedagogical University. p 3-25.

Skripkin VV, Kovalyukh NN. 1998. Recent developments in the procedures used at the SSCER laboratory for the routine preparation of lithium carbide. Radiocarbon 40(1):211-4.

Van Strydonck M, Boudin M, Ervynck A. 2004. Possibilities and limitations of the use of stable isotopes $\left(\delta^{13} \mathrm{C}\right.$ and $\delta^{15} \mathrm{~N}$ ) from human bone collagen and carbonate as an aid in migration studies. In: Scott EM, Alekseev
AY, Zaitseva G, editors. Impact of the Environment of Human Migration in Eurasia. NATO Science Series, Volume 42. Dordrecht: Kluwer Academic. p 125-35.

Vasil'ev IB, Vybornov AA. 1988. Neolit Povolzh'ya. Kuibyshev: State Pedagogical Institute.

Vybornov AA. 1990. Neolit Severnogo Prikaspiya I ego sootnoshenie s kul'turami sopredelk'nyh territorii. In: Vasil'ev IB, editor. Problemy drevnei istorii Severnogo Prikaspiya. Kuibyshev: State Pedagogical Institute.

Vybornov AA. 2008. The Neolithic of the Volga-Kama Rivers Basin. Samara: Samara State Pedagogical University Monograph. In Russian.

Yudin AI. 2005. Low Volga cultural community of the Neolithic: the problems of formation, contacts and evolution. In: Proceedings of the Scientific Conference Devoted to the 100th Anniversary of V.A. Gorodtsov in the State Historical Museum. April 2003. Moscow. p 7-17. In Russian. 